\title{
PERAN KEPEMIMPINAN KEPALA MADRASAH DALAM MENINGKATKAN BUDAYA DISIPLIN SISWA DI MAS PATRA MANDIRI PLAJU PALEMBANG
}

\section{Sandy Surya ${ }^{1}$, Ahmad Zainuri ${ }^{2}$, Sayid Habiburrahman ${ }^{3}$}

${ }^{1,2}$ Universitas Islam Negeri Raden Fatah Palembang, ${ }^{3}$ Universitas Muhammadiyah Palembang E-mail: sandysurya04@gmail.com, ahmadzainuri_uin@radenfatah.ac.id, sayidhabiburrahman@gmail.com

How to Cite:

Surya, S., Zainuri, A., Habiburrahman, S.,(2020). Peran Kepemimpinan Kepala Madrasah dalam Meningkatkan Budaya Disiplin Siswa di MAS Patra Mandiri Plaju Palembang. Fitrab: Journal of Islamic Education, 1(2), 289-300.

\begin{tabular}{ll}
\hline ARTICLE HISTORY \\
Received & $: 13$ December 2020 \\
Revised & $: 11$ February 2021 \\
Accepted & $: 12$ February 2021 \\
Published $: 17$ February & 2021
\end{tabular}

\section{KEYWORDS:}

Discipline Culture, Head Master, Leadership.

\section{ABSTRACT}

Discipline culture is a reflection of the quality of educational institutions. The low level of discipline is the main problem of every educational institution. The role of leadership is very much needed in overcoming this problem. This paper aims to describe the leadership role of madrasah principals in improving the disciplinary culture of students at MAS Patra Mandiri Plaju Palembang. This research uses a qualitative approach with a descriptive analytic study method. Data were collected using interview techniques, observation and documentation study. The results of this study indicate that the headmaster of MAS Patra Mandiri Plaju Palembang has played its role and function in improving the disciplinary culture of students in a fairly good category. This is supported by 2 factors, namely (1) the role models of madrasah principals in complying with school regulations; and (2) socialization of school discipline rules and sanctions for violations. The obstacles faced by madrasah principals are (1) there are still some teachers who do not exemplify student attitudes; and (2) there are still students who are not "deterred" to be given disciplinary violations.

\section{RIWAYAT ARTIKEL}

Diterima : 13 Desember 2020

Direvisi : 11 Februari 2021

Diterima : 12 Februari 2021

Diterbitkan : 17 Februari 2021

\section{KATA KUNCI:}

Budaya Disiplin, Kepala Madrasah, Kepemimpinan.

\begin{abstract}
ABSTRAK
Budaya disiplin merupakan cerminan kualitas pada satuan lembaga pendidikan. Rendahnya tingkat kedisiplinan menjadi problematika utama setiap lembaga pendidikan. Peran pimpinan sangat dibutuhkan dalam mengatasi masalah ini. Tulisan ini bertujuan untuk mendeskripsikan peran kepemimpinan kepala madrasah dalam meningkatkan budaya disiplin siswa di MAS Patra Mandiri Plaju Palembang. Penelitian ini menggunakan pendekatan kualitatif dengan metode studi deskriptif analitik. Pemerolehan data dilakukan dengan menggunakan teknik wawancara, observasi dan studi dokumentasi. Hasil penelitian ini menunjukkan bahwa kepala madrasah MAS Patra Mandiri Plaju Palembang telah menjalankan peran dan fungsinya dalam meningkatkan budaya disiplin siswa dalam kategori cukup baik. Hal ini didukung 2 faktor, yaitu (1) keteladanan kepala madrasah dalam mematuhi peraturan madrasah; dan (2) sosialisasi tata tertib kedisiplinan madrasah dan sanksi pelanggaran. Adapun kendala yang dihadapi kepala madrasah yaitu, (1) masih terdapat beberapa guru yang tidak mencontohkan sikap teladan pada siswa; dan (2) masih terdapat siswa yang tidak "jera-jera" diberi sanksi pelanggaran disiplin.
\end{abstract}




\section{PENDAHULUAN}

Kepala madrasah merupakan satu komponen yang paling berperan dalam meningkatkan kualitas pendidikan, yang memiliki tanggung jawab lebih dibandingkan dengan pendidik dan tenaga kependidikan di madrasah (Manora, 2019). Madrasah seperti memberikan tanggung jawab yang berlebih untuk memajukan pendidikan yang ia pimpin (Ekosiswoyo, 2016). Seperti diungkapkan Setiyati (2014), bahwa "Erat hubungannya antara mutu kepala Madrasah dengan berbagai kehidupan madrasah seperti disiplin madrasah, iklim budaya madrasah, dan menurunnya prilaku nakal peserta didik. Bila kepala madrasah kurang mampu atau kurang terampil dalam mengelola madrasah maka secara tidak langsung akan mempengaruhi kegiatan proses belajar mengajar yang akhirnya mempengaruhi prestasi belajar. Dalam keadaan ini, diperlukan peran kepala madrasah untuk meningkatkan kegiatan proses belajar mengajar di madrasah. Kepala madrasah harus mampu meningkatkan budaya disiplin di madrasah sehingga guru dan siswanya merasa cinta kepada peraturan-peraturan atau disiplin-disiplin yang berlaku di madrasah (Najmudin et al., 2019).

Madrasah yang membudayakan disiplin akan melahirkan kondisi yang baik, nyaman, tentram dan teratur. Menurut Hadianti (2017), sivitas madrasah khususnya pimpinan "wajib" memberi keteladanan bagi siswa tentang budaya disiplin, yakni taat pada aturan yang berlaku di madrasah. Lebih lanjut, Tua et al. (2014) menerangkan bahwa kepatuhan terhadap aturan berlaku di madrasah membutuhkan kesadaran dari diri pendidik dan peserta didik, inilah tugas pimpinan memprogramkan upaya peningkatan kesadaran budaya disiplin.

Peranan kepala madrasah dalam membina disiplin di madrasah baik terhadap guru maupun terhadap siswa dalam menunaikan tugasnya masingmasing sangat menunjang tercapainya hasil secara maksimal. Melalui disiplin yang baik siswa dapat teransang untuk menjalankan tugas dan tanggung jawabnya dengan baik sehingga kegiatan Pendidikan di madrasah akan berjalan dengan baik. (Indah Cahyani, 2016; Assingkily \& Mesiono, 2019)

Masalah kedisiplinan siswa menjadi sangat berarti bagi kemajuan madrasah. Di madrasah yang taat terhadap peraturan, akan selalu mendapatkan proses pembelajaran yang baik (Sugeng, 2016; Syafaruddin, et. al., 2020). Sebaliknya, dimadrasah yang tidak tertib kondisinya akan jauh berbeda dari madrasah yang disiplin. Pelanggaranpelanggaran yang terjadi sudah dianggap barang biasa dan untuk meperbaiki keadaan demikian tidaklah mudah. Hal ini diperlukan kerja keras dari berbagai pihak untuk mengubahnya, terutama kepala madrasah yang sangat berperan sekali dalam mendisiplinkan siswa. (Christenson et al., 2014).

Salah satu cara mengukur kemampuan kepala madrasah dalam memimpin madrasahnya adalah dalam mendisiplinkan siswa. Bahkan berhasil tidaknya suatu madrasah dalam persoalan disiplin sangat tergantung kepada kepala madrasah sebagai orang yang bertanggung jawab dalam lembaga pendidikan tersebut. Oleh karenanya, disiplin dapat digunakan 
sebagai barometernya dan kepala madrasah memiliki andil yang sangat besar dalam menjalankan dan melaksanakan setiap peraturan yang dibuat dengan sebaikbaiknya. (Kurniasih \& Wijaya, 2019).

Berdasarkan hasil pengamatan awal di MA Patra Mandiri Plaju pada tanggal 03-08 April 2019, jam 07:00-selesai menunjukkan bahwa terdapat siswa yang melakukan pelanggaran-pelanggaran terhadap tata tertib madrasah. Dengan adanya masalah tersebut, peneliti ingin mengetahui, tindakan apa yang dilakukan untuk menertibkannya, hal ini dapat dilihat dengan gejala-gejala seperti Adanya siswa yang datang terlambat, Masih adanya siswa yang tidak berpakain rapi, Adanya siswa yang bermain di halaman madrasah pada jam pelajaran, Masih adanya siswa yang tidak mengerjakan pekerjaan rumah.

Berperilaku tidak Disiplin juga berpengaruh banyak terhadap menurunnya prestasi siswa. Selain faktor lingkungan disiplin juga biasanya mengalami penurunan karena faktor teman dekat, seperti karena kita terlalu menghargai teman sehingga sering menghabiskan waktu untuk mengobrol bersama-sama, ketimbang belajar. Padahal keesokan harinya akan menghadapi ujian atau ada tugas madrasah yang harus dikerjakan.

Kondisi tersebut dapat mengakibatkan prestasi madrasah menurun, yang nantinya akan membuat guru, dan orang tua menjadi kecewa. Kelalaian atau ketidak disiplinan dalam menyimak dan mengulang pelajaran seringkali membuat kita mengambil jalan pintas, menyontek pada waktu ulangan. Padahal ini hanya akan memperkeruh keadaan, menimbulkan persoalan baru seperti sanksi dari guru atau semakin tidak mengertinya siswa terhadap suatu pembelajaran

Sehubungan dengan gejala di atas, penulis tertarik dan berkeinginan untuk mengetahui lebih lanjut dengan melakukan penelitian ilmiah yang berjudulkan "Peran Kepemimpinan Kepala Madrasah dalam Meningkatkan Budaya Disiplin Siswa di MA Patra Mandiri Plaju Palembang”.

\section{KAJIAN TEORI}

Peran kepala madrasah dalam menggerakan kehidupan madrasah untuk mencapai tujuannya adalah peran yang sangat penting. Ada dua hal yang perlu diperhatikan dalam rumusan tersebut. (1) Kepala madrasah menjadi kekuatan sentral yang menjadi kekuatan penggerak kehidupan madrasah. (2) Kepala madrasah harus memahami tugas dan fungsi mereka demi keberhasilan madrasah serta memiliki kepedulian pada staf dan siswa. (Wahjosumidjo, 2010: 84).

Kepala madrasah adalah jabatan pemimpin yang tidak bisa diisi oleh orang tanpa didasarkan atas pertimbanganpertimbangan. Siapapun yang akan diangkat menjadi kepala madrasah harus ditentukan melalui prosedur serta persyaratan tertentu seperti latar belakang, pendidikan, pengalaman, usia, pangkat, dan integritas. (Zahro et al., 2018).

Sesuai dengan ciri-ciri madrasah sebagai organisasi yang bersifat Kompleks dan unik, tugas dan fungsi kepala madrasah dapat dipandang sebagai pejabat formal, sedang dari sisi lain kepala madrasah dapat berperan sebagai pendidik (educator),manajer, 
administrator, supervisor, pemimpin (leader), dan kepala madrasah juga berperan sebagai staf. Malayu Hasibuan mendefinisikan pemimpin (leader) adalah seorang dengan wewenang kepemimpinannya mengarahkan bawahannya untuk mengerjakan sebagian dari pekerjaannya dalam mencapai tujuannya melalui kegiatan-kegiatan orang lain. (Kurnianingsih, 2018).

Kepala madrasah selaku seorang pemimpin harus mampu memengaruhi, memotivasi dan adanya bimbingan para bawahannya yaitu guru-guru dan karyawan agar mereka dengan penuh kemauan serta sesuai dengan kemampuan secara maksimal berusaha mencapai tujuan organisasi. Kepala madrasah merupakan contoh teladan dalam setiap perilaku bagi semua bawahan dalam lingkungannya. (Fitrah, 2017). Kemampuan yang harus diwujudkan kepala madrasah sebagai leader dapat dianalisis dari kepribadian, pengetahuan terhadap tenaga kependidikan, visi dan misi madrasah, kemampuan mengambil keputusan dan kemampuan komunikasi dua arah. (Purwaningsih \& Herwin, 2020).

Hal-hal yang perlu diperhatikan Kepala madrasah sebagai leader dalam meningkatkan disiplin yaitu:

Pertama, Memberi arahan/ pembinaan dan bimbingan. Hadan nawawi mengemukakan tentang pembinaan dan bimbingan disiplin adalah kegiatan yang bertujuan mengarahkan agar semua orang dalam organisasi kelompok kerja sama mengerjakan hal-hal yang terdapat sesuai dengan petunjuk yang hendak dicapai. (Afifan Zaqiyan, 2016). Usaha kepala madrasah dalam rangka pembinaan guru, dan siswa untuk meningkatkan disiplin, tentu sudah sewajarnya mempuyai program, program kepala madrasah dalam disiplin madrasah yaitu : Perumusan peraturan disiplin secara rinci dan jelas, Pertemuan rutin kepala madrasah dengan guru-guru, Rapat kepala madrasah dengan guru-guru, Kunjungan kepala madrasah ke kelas-kelas. (Tamarli, 2009).

Kedua, Keteladanan. Kepala madrasah yang ekstropet adalah kepala madrasah yang sering dijadikan idola dan contoh bagi bawahan. Bentuk keteladanan yang diberikan yaitu datang setiap pagi sebelum siswa yang lain datang atau guru datang, jika ada guru yang terlambat besoknya akan memperbaiki, membantu staf kebersihan memungut sampah yang berserakan, dari contoh ini penghuni madrasah perlahan akan mengikuti, Selalu keliling dari kelas ke kelas dan memastikan proses KBM berjalan lancer, kepala madrasah tidak membatasi siswa,guru dan kepala madrasah untuk saling berkomunikasi sebagai keluarga atau teman. (Andriyani, 2013).

Ketiga, Memberi Motivasi kepada seluruh komponen organisasi. Motivasi merupakan latar belakang yang menggerakan atau mendorong orang untuk melakukan sesuatu. Dengan kata lain, motivasi merupakan suatu landasan psikologis (kewajiban) yang sangat penting bagi setiap orang dalam melaksanakan sesuatu aktivitasnya. Apalagi aktivitas itu berupa tugas yang menuntut tangung jawab yang tingggi. Menurut Ahmad Sohnaji beberapa indikator sukses memotivasi orang lain berupa : Menguasai kekuatan pujian kepada siswa/guru, Mengatakan kepada siswa/guru 
bahwa mereka kelihatan bagus jika disiplin, Pujian kepada siswa atas usahanya, Berbicara dengan apa yang baik jangan menggujing, Akuilah prestasinya. (Sulhan, 2018).

Jadi dapat disimpulkan bahwa peran kepala madrasah sebagai leader dalam disiplin adalah seseorang yang memberi arahan/pembinaan dan bimbingan, motivasi serta teladan dalam meningkatkan disiplin. Disiplin merupakan kepatuhan untuk menghormati dan melaksanakan suatu sistem yang mengharuskan orang untuk tunduk pada keputusan, perintah atau peraturan yang berlaku. Dalam bahasa indonesia istilah disiplin kerap kali terkait dan menyatu dengan istilah tata terti dan ketertiban. Siswa adalah setiap orang yang datang ke suatu lembaga untuk mendapatkan atau mempelajari berbagai macam pendidikan. (Tu'u, 2004).

Indikator disiplin siswa itu seperti: menyelesaikan tugas pada waktunya, selalu mengajak teman menjaga ketertiban kelas, berpakain sopan dan rapi, mematuhi aturan madrasah, saling menjaga dengan teman agar semua tugas-tugas kelas terlaksana dengan baik. Dalam penanggulangan disiplin, beberapa hal berikut ini perlu di perhatikan yaitu: Adanya tata tertib, Konsisten dan konsenkuen, Hukuman, Kemitraan dengan orang tua. (Tu'u, 2004; Alfiansyah, et. al., 2020)

Ada beberapa hal yang dapat mendukung dan menghambat disiplin siswa. Faktor yang mendukung antara lain:

- Teladan

Perbuatan dan tindakan kerap kali lebih besar pengaruhya dibandingkan dengan kata-kata.
Karena itu, contoh dan teladan disiplin atasan, kepala madrasah dan guru-uru serta usaha sangat berpengaruh terhadap disiplin para siswa. Mereka lebih mudah meniru apa yang mereka lihat dibandingkan apa yang mereka dengar. (Cahyaningrum et al., 2017).

- Tata tertib

Peraturan madrasah merupakan pedoman yang digunkana oleh siswa. Peratura memiliki peranan yang penting untuk menata tingkah laku seseorang. Hali ini sesuai dengan pendapat Maria yang mengatakan bahwa peraturan memiliki dua fungsi yang penting dalam membantu anak untuk menjadi manusia yang disiplin. Pertama peraturan memiliki nilai pendidikan dan yang kedua peraturan membantu mengekang perilaku yang tidak diinginkan. Konsenkuensi dengan adanya peraturan adalah penerapan hukuman yang mendidk. Hukuman yang mendidik dapat membiasakan anak untuk selalu disiplin, hal ini pun sesuai dengan pendapat Schafer yang mengatakan bahwa ada dua tujuan dalam peneraan hukuman, pertama tujuan jangka pendek dan yang kedua tujuan jangka panjang. (Trisnawati, 2013).

- Hukuman

Hukuman bertujuan mencegah tindakan yang tidak baik atau tidak diinginkan. Tujuan hukuman menurut Hadisubrata 
yaitu untuk mendidik dan menyadarkan siswa bahwa perbuatan yang salah mempuyai akibat yang tidak menyenangkan. Hukuman diperlukan juga untuk mengendalikan perilaku disiplin, tetapi hukuman bukan satu-satunya cara untuk mendisiplinkan siswa. (Novitasari, 2019).

- Administrasi

Setiap pelangaran yang terjadi harus dicata oleh bagian administrasi yang ditugaskan khusus mencatat pelanggaran tata tertib madrasah. Administrasi ini perlu dibuat rapi dan sistematis.tujuannya agar kita dapat melihat data siswa yang bermasalah dengan disiplin madrasah. (Rohman, 2018).

Adapun beberapa hal yang menghambat disipilin siswa seperti yang tertera di bawah ini:

- Guru kurang memberi teladan

Dalam rangka menerapkan dan mengembangkan disiplin madrasah, kadang- kadang ada guru yang belum berhasil memberi tauladan yang baik. Guru seperti ini akan menjadi tantagan dalam menerapkan dan mengembangkan disiplin madrasah. Agar tidak ada kesulitan, guru yang belum atau kurang memberi teladan disiplin diri yang baik, dimintakan dukunganya dalam pengembangan disiplin madrasah

- Siswa tidak jera-jera

Ketika disiplin madrasah yang ketat dan konsekuen dilaksanakan,pasi ada siswa yang terkena pelanggaran.
Mereka yang melanggar disiplin madrasah harus betanggung jawab dengan menerima sanksi disiplin madrasah. (Tu'u, 2004).

\section{METODE PENELITIAN}

Jenis penelitian ini mengunkana jenis penelitian field research (penelitian lapangan). Penelitian lapangan adalah penelitian yang dilakukan dengan menggunakan informasi yang diperoleh penulis di tempat penelitian. Penelitian lapangan merupakan penelitian kualitatif di mana peneliti mengamati dan berpartisipasi secara langsung dalam penelitian sosial skala kecil dan mengamati budaya setempat.

Dalam penelitian ini, peneliti ingin mengambarkan tentang peran kepala madrasah dalam mendisiplinkan siswa di MA patra mandiri plaju. Oleh karena itu penelitian ini mengunakan penelitian deskriptif dengan pendekatan kualitatif. Pendekatan penelitian ini menggunakan pendekatan kualitatif artinya pendekatan yang dilakukan dengan menjelaskan, menerangkan, dan menguraikan pokok permasalahan yang hendak dibahas dalam penelitian ini kemudian ditarik kesimpulan secara deduktif (Saipul, 2008: 29). Penalaran deduktif adalah kegiatan berpikir yang sebaliknya dari penalaran induktif. Deduktif adalah cara berpikir di mana dari pernyataan yang bersifat umum ditarik kesimpulan yang bersifat khusus. Dalam penelitian ini, peneliti ingin menggambarkan tentang Peran Kepala Madrasah Sebagai Leader dalam Mendisiplinkan Siswa di Ma Patra Mandiri plaju.

Informasi pendidikan adalah 
orang-orang yang benar-benar mengetahui dan terlibat langsung dengan fokus permasalahan yang ada sehingga peneliti dapat merangkum informasi penting dalam fokus penelitiannya. Informan kunci adalah mereka yang mengetahui dan memiliki berbagai informasi pokok yang diperlukan oleh penelitian. Dalam hal ini yang menjadi informan kunci adalah kepala madrasah. Sedangkan, Informan pendukung adalah mereka yang dapat memberi informasi tidak terlibat langsung dalam interaksi sosial yang diteliti. Dalam hal ini yang menjadi informasi pendukung adalah siswa.

Teknik pengumpulan data yang digunakan dalam penelitian ini yakni melalui wawancara, observasi dan dokumentasi. Sedangkan teknik analisis data peneliti menggunakan teori Miles dan Huberman, bahwa analisis data kualitatif terdiri atas empat tahap, yaitu: reduksi data (data reduction), penyajian data (data display), penarikan kesimpulan (condution drawing), dan verifikasi.

\section{HASIL DAN PEMBAHASAN PENELITIAN}

Hasil penelitian akan dijelaskan berdasarkan tujuan penelitian sebagaimana yang telah disebutkan sebelumnya. Hasil penelitian tersebut lalu dianalisis untuk mendapatkan pendalaman pembahasan. Hasil penelitian ini menunjukkan bahwa peran kepemimpinan kepala madrasah sangat berdampak pada peningkatan budaya disiplin siswa. Lebih lanjut, diuraikan pada poin-poin pembahasan di bawah ini.

\section{Peran kepala madrasah sebagai leader dalam mendisiplinkan siswa}

Dalam bagian ini, penelti menganalisis di lapangan yang sesuai juga dengan rumusan masalah yang selanjutnya dikaitkan dengan teori yang ada yaitu tentang peran kepala madrasah sebagai leader dalam mendisiplin siswa di MA Patra mandiri plaju.

1. Memberi arahan/pembinaan dan bimbingan

Kepala madrasah sebagai pemimpin dalam meningkatkan kemajuan madrasah selalu mengadakan pembinaan guru, terhadap siswa dalam meningkatkan disiplin di madrasah. Hadan nawawi mengemukakan tentang pembinaan dan bimbingan disiplin adalah kegiatan yang bertujuan mengarahkan agar semua orang dalam organisasi kelompok kerja sama mengerjakan hal-hal yang terdapat sesuai dengan petunjuk yang hendak dicapai.

Dari pendapatkan tersebut dapat disimpulkan bahwa pengarahan yang diberikan untuk semua orang yang melakukan kegiatan-kegiatan sesuai dengan wewenang dan tanggung jawabnya masing-masing. Bimbingan dan pengarahan yang diberikan itu harus secara kntinyu agar seluruh kegiatan selalu terarah pada pencapain tujuan yang telah ditetapkan. Kepala madrasah memegang peranan penting dalam meningkatkan mutu pendidikan di madrasah yang dipimpinnya. Mutu pendidikan akan baik bila disiplin di madrasah tercipta dengan baik

Pelaksanaan peran kepala madrasah dilakukan dengan melakukan pembinaan disiplin, adapun usaha yang harus dilakukan dalam membina yaitu : Perumusan peraturan disiplin secara rinci dan jelas, Pertemuan rutin kepala madrasah dengan guru-guru, Rapat kepala madrasah dengan guru-guru, 
Kunjungan kepala madrasah ke kelas-kelas. Semuanya harus dilakukan sesuai yang telah dijelaskan dari teori di atas.

Dari hasil obsevasi, wawancara, dan dokumentasi yang peneliti dapatkan di lapangan bahwa peneliti dapat mengambil kesimpulan bahwa pembinaan dan bimbingan yang dilakukan oleh kepala madrasah telah dilakukan dengan baik mulai dari memberi arahan dalam bentuk lisan atau pun tulisan dan observasi secara lansung untuk melihat sejauh mana siswa menaati tata tertib yang berlaku. Apalagi di madrasah terdapat papan peraturan/tata tertib yang sudah dibuat untuk ditaati oleh warga madrasah terutama siswa yang ada di madrasah.

\section{Keteladanan}

Kepala madrasah sebagai pemimpin yang baik selalu berusaha menjadi teladan bagi stakeholder lainnya. Sebagai pemimpin kepala madrasah harus mampu menjadi pemimpin yang dapat di contoh perilaku dan tindakanya.pemimpin harus menjadi transenter atau interainmen di dalam pendidikan.

Yang di maksud dengan memberi contoh adalah dapat menjadi orang yang terdepan, tauladan dan segala perilakunya yang positif dapat ditiru oleh bawahanya dalam hal ini guru dan siswa. Kepala madrasah yang ekstropet adalah kepala madrasah yang sering dijadikan idola dan contoh bagi bawahan.

Berdasarkan hasil wawancara di atas mengenai keteladanan yang diberikan oleh kepala madrasah kepada warga madrasah terutama siswa dimadrasah, ada yang telah dilakukan oleh kepala madrasah belum menjadi bentuk keteladanyang baik dilakukan oleh kepala madrasah, seperti datang pada saat bel berbunyi. Itu mejadi suatu kendala yang tidak bisa disembunyikan. Karena disini kepala madrasah ialah motor pengerak dan juga orang yang patut ditiru oleh warga madrasah lainya.

Selain itu juga peraturan yang dibuat dimadrasah yang diletakan dimadrasah hanya peraturan untuk siswa, sedangkan tata tertib untuk guru dan kepala madrasah pun tidak ada. Ini menjadi hal yang paling utama yang mendisiplin warga madrasah. Keteladanan merupakan usahan meniru sikap dari tokoh atau yang dapat dicontohkan dari tokoh tersebut. Mulai dari watak tokoh,selalu ada sifat-sifat baik dapat diteladani untuk diterapkan dalam kehidupan sehari-hari.

Dari hasil obsevasi dan wawancara yang peneliti dapatkan di lapangan bahwa peneliti dapat mengambil kesimpulan bahwa bentuk keteladanan yang diberikan oleh kepala madrasah belum sesuai dengan sebagaimana mestinya. Diharapkan untuk selanjutnya kepala madrasah harus memberikan contoh atau bentuk keteladan yang baik untuk warga madrasah, terutama kepada siswa madrasah.

\section{Motivasi}

Motivasi merupakan upaya untuk membangkitkan semangat. Motivasi diberikan parapimpinan agar bawahannya selalu semangat dalam bekerja (Slamet Andriyani, 2013). Motivasi merupakan latar belakang yang menggerakan atau mendorong orang untuk melakukan sesuatu. Dengan kata lain, motivasi merupakan suatu landasan psikologis (kewajiban) yang sangat penting bagi setiap orang dalam 
melaksanakan sesuatu aktivitasnya. Apalagi aktivitas itu berupa tugas yang menuntut tangung jawab yang tingggi.

Dalam menegakan disiplin, mungkin berawal berdasarkan motivasi ekstrinksik (motivasi dari luar). Oran melakukan sesuatu karena paksaan, pengaruh orang lain, atau karena keinginan tertentu. Akan tetapi setelah berproses orang tersebut dapat saja berubah kea rah instrinksik ( motivasi dari dalam).

Setelah merasakan bahwa dengan menerapkan disiplin memliki dampak positif bagi dirinya kemudian orang tersebut melakukan sesuatu dilandasi dengan kesadaran dari dalam dirinya sendiri. Idealnya menegakkan disiplin itu sebaiknya dilandasi oleh sebah kesadaran. Kepala madrasah harus mampu meningkatkan disiplin di madrasah sehingga guru, karyawan, dan siswanya merasa cinta kepada peratranperaturan atau disiplin-disiplin yang berlaku di madrasah

Dari hasil wawancara dan observasi yang dilakukan oleh peneliti dapat diketahui bahwa motivasi yang diberikan oleh kepala madrasah kepada warga madrasah terutama siswa sudah berjalan sebagaimana mestinnya seperti memberikan penghargaan kepada siswa yang mendapatkan penghargaan, tentu saja itu ada kategori-kategori yang menjadi dasar terbentuknya penghargaan tersebut. jika sudah diterapkan diharapkan siswa/i dapat menjalankan disiplin dengan baik dan benar.

\section{Hambatan yang di hadapi dalam mendisiplinkan siswa}

Ada beberapa hambatan yang
dihadapi oleh kepala madrasah dalam

mendisiplinkan siswa di MA Patra Mandiri Plaju Palembang. Namun sebelum dikemukakan, terlebih dahulu perlu dijelaskan bahwa hambatan ini pada dasarnya tidak hanya dialami oleh kepala madrasah saja melainkan juga dialami oleh tenaga pengajar di madrasah tersebut. Hambatan ini memang jika tidak diatasi maka akan menjadi problem yang lebih besar lagi. Beberapa hambatan yang dimaksud ialah:

1. Kurangnya kerjasama orang tua dan pihak madrasah

Kerjasama orang tua dalam hal mendisiplinkan siswa memang menjadi hal yang paling utama, tanpa adanya kerjasama sulit rasanya untuk menegakkan disiplin. Namun hal itu tidak terjadi di madrasah tersebut, orang tua kerap tidak dapat menumjukkan kerjasama yang baik, kedisiplinan hanya ditegakkan dimadrasah akan tetapi di rumah tidak dibiasakan, sehingga anak menjadi tidak terbiasa untuk disiplin dimadrasah. Selain itu terdapat beberapa orang tua yang tidak suka dengan hukuman yang diberikan kepada siswa. Hal ini ditunjukkan dengan sikap kritik yang terkadang disampaikan kepada kepala madrasah ataupun tenaga pengajar.

Temuan kritik dari orang tua menjadi novelty dalam penelitian ini, dimana hambatan terbesar pada dasarnya tidak terletak pada siswanya akan tetapi terletak dari orang tua. Sehingga perubahan sulit untuk dilakukan, karena kerap siswa menjadi berani untuk melakukan kesalahan terutama dalam hal ketidakdisiplinan.

2. Pemberian hukuman yang tidak konsisten

Kepala madrasah selalu memberikan 
arahan kepada guru untuk selalu memberikan hukuman yang seimbang dengan kesalahan yang dilakukan oleh siswa, dan konsisten dalam pemberiannya. Namun terkadang kerap kali guru tidak memberikan hal yang demikian hal ini dikarenakan pertimbangan perasaan yang terkadang muncul dari guru wanita. Perlakuan semacam ini terkadang tidak diketahui kepala madrasah, sehingga akhirnya berdampak pada penurunan kedisiplinan anak. Sebenarnya hal ini didasari dari prinsip bahwa semakin konsisten dalam mendidik kedisiplinan anak maka akan menghantarkan anak dalam sikap disiplin yang stabil dan kokoh pada siswa. Novelty kedua dalam penelitian ini bahwa kedisiplinan akan tercipta dengan prinsip konsistensi

3. Orientasi hukuman yang diterapkan guru tidak pada efek jera

Hukuman memang diberikan kepada sikap yang tidak disiplin, akan tetapi kadang kala hukuman memang tidak membuat efek jera kepada siswa. Hal ini kadang kala dipengaruhi oleh kemauan dan motivasi siswa memang sangat sulit untuk merubah sikapnya. Dalam hal ini memang motivasi menjadi sangat penting dalam kedisiplinan ia menjadi salah satu alasan kuat mengapa siswa tersebut mau untuk menjadi orang yang disiplin dalam segala hal. Baik motivasi internal atau motivasi eksternal.

4. Kesibukan kepala madrasah

Faktor pengawasan juga menjadi kunci keberhasilan tegaknya disiplin di madrasah. Fungsi pengawasan menjadi tugas kepala madrasah, dan dalam hali ini tugasnya terimplementasi dalam bentuk penegakan kedisiplinan siswa. Kedisiplinan menjadi sangat penting untuk diawasi sebab jika tidak maka siswa akan dengan sengaja untuk melanggarnya. Hal ini memang menjadi hambatan bagi kepala madrasah sebab selain berfungsi menjadi tenaga pengajar, kepala madrasah memiliki tugas utama dalam hal leader atau pemimpin yang bertanggung jawab baik dalam hal administrasi maupun pembelajaran, tentulah hal ini membuat kesibukan kepala madrasah menjadi dua kali lipat lebih banyak dari guru lainnya.

\section{SIMPULAN}

Berdasarkan hasil penelitian dan pembahasan yang telah peneliti lakukan, disimpulkan bahwa kepala madrasah MAS Patra Mandiri Plaju Palembang telah menjalankan peran dan fungsinya dalam meningkatkan budaya disiplin siswa dalam kategori cukup baik. Hal ini didukung 2 faktor, yaitu (1) keteladanan kepala madrasah dalam mematuhi peraturan madrasah; dan (2) sosialisasi tata tertib kedisiplinan madrasah dan sanksi pelanggaran. Adapun kendala yang dihadapi kepala madrasah yaitu, (1) masih terdapat beberapa guru yang tidak mencontohkan sikap teladan pada siswa; dan (2) masih terdapat siswa yang tidak "jera-jera" diberi sanksi pelanggaran disiplin.

\section{DAFTAR PUSTAKA}

Afifan Zaqiyan, A. (2016). Peran Kepala Madrasah dalam Pelaksanaan Budaya Disiplin Siswa Di SMP Negeri 1 Krembung Kabupaten Sidoarjo. Inspirasi Manajemen Pendidikan,4(1),1-10. https:// jurnalmahasiswa.unesa.ac.id/index. php/inspirasi-manajemen-pendidikan/ article/viewFile/16641/15117 
Alfiansyah, M., et. al. (2020). Kebijakan Internal Madrasah dalam Meningkatkan Mutu Pendidikan di MI Nurul Ummah Kotagede Yogyakarta. MAGISTRA: Media Pengembangan Ilmu Pendidikan Dasar dan Keislaman, 11(1), 52-67. https://publikasiilmiah. unwahas.ac.id/index.php/magistra/ article/view/3460

Andriyani, S. (2013). Peran Kepemimpinan Kepala Madrasab Dalam Menumbubkan Kedisiplinan Guru dan Karyawan di SMK Negeri 1 Surakarta [UNS (Sebelas Maret University)]. https://digilib.uns. ac.id/dokumen/detail/30670/Perankepemimpinan-kepala-madrasahdalam-menumbuhkan-kedisiplinanguru-dan-karyawan-di-SMK-Negeri1-Surakarta

Assingkily, Muhammad Shaleh \& Mesiono. (2019). Karakteristik Kepemimpinan Transformasional di Madrasah Ibtidaiyah (MI) serta Relevansinya dengan Visi Pendidikan Abad 21. Manageria: Jurnal Manajemen Pendidikan Islam, 4(1), 147-168. http://ejournal. uin-suka.ac.id/tarbiyah/index.php/ manageria/article/view/2475.

Cahyaningrum, E. S., Sudaryanti, S., \& Purwanto, N. A. (2017). Pengembangan Nilai-Nilai Karakter Anak Usia Dini Melalui Pembiasaan dan Keteladanan. Jurnal Pendidikan Anak, 6(2), 203-2013. https://doi. org/10.21831/jpa.v6i2.17707

Christenson, N., Chang Rundgren, S.-N., \& Zeidler, D. L. (2014). The Relationship of Discipline Background to Upper Secondary Students' Argumentation on Socioscientific Issues. Research in Science Education, 44(4), 581-601. https://doi.org/10.1007/s11165013-9394-6

Ekosiswoyo, R. (2016). Kepemimpinan Kepala Madrasah Yang Efektif Kunci
Pencapaian Kualitas Pendidikan. Jurnal Ilmu Pendidikan, 14(2), 76-82. http:// dx.doi.org/10.17977/jip.v14i2.24

Fitrah, M. (2017). Peran Kepala Madrasah dalam MeningkatkanMutu Pendidikan. Jurnal Penjaminan Mutu, 3(1), 31-42. http://dx.doi.org/10.25078/jpm. v3i1.90

Hadianti, L. S. (2017). Pengaruh Pelaksanaan Tata Tertib Madrasah Terhadap Kedisiplinan Belajar Siswa (Penelitian Deskriftif Analisis di SDN Sukakarya II Kecamatan samarang Kabupaten Garut). Jurnal Pendidikan UNIGA, 2(1), 1-8. http://journal.uniga.ac.id/ index.php/JP/article/view/11

Indah Cahyani, L. (2016). Peran Kepala Madrasah dalam Penanaman Pendidikan Karakter Disiplin di SMA Cendekia Sidoarjo. Inspirasi Manajemen Pendidikan, 4(1), 1-7. https://jurnalmahasiswa.unesa.ac.id/ index.php/inspirasi-manajemenpendidikan/article/view/17311

Kurnianingsih, E. (2018). Peran Kepala Madrasah dalam Meningkatkan Kompetensi Guru. Indonesian Journal of Education Management \& Administration Review, 1(1), 11-18. http://dx.doi. org/10.4321/ijemar.v1i1.932

Kurniasih, F., \& Wijaya, H. (2019). Peran Kepemimpinan Kepala Madrasah Dalam Meningkatkan Kedisiplinan Siswa di SDN Embung Tangar Kecamatan Praya Barat. JUPE: Jurnal Pendidikan Mandala, 4(5), 326-334. http://dx.doi.org/10.36312/jupe. v4i5.937

Manora, H. (2019). Peranan Kepala Madrasah dalam Meningkatkan Mutu Pendidikan. Edification Journal, 1(1), 119-125. https://doi.org/10.37092/ ej.v1i1.88

Najmudin, N., Fauzi, F., \& Ikhwani, I. 
(2019). Program kedisiplinan siswa di lingkungan madrasah: Studi Kasus di Dayah Terpadu (Boarding School) SMA Babul Maghfirah Aceh Besar. Edukasi Islami: Jurnal Pendidikan Islam, 8(02), 183-206. http://dx.doi. org/10.30868/ei.v8i2.430

Novitasari, A. (2019). Pemberian Reward and Punishment dalam Membentuk Karakter Disiplin Anak pada Madrasah Madrasah Ibtidaiyah. Halaqa: Islamic Education Journal, 3(1), 27-33. http:// doi.org/10.21070/halaqa.v3i2.2873

Purwaningsih, A. Y., \& Herwin, H. (2020). Pengaruh Regulasi Diri dan Kedisiplinan Terhadap Kemandirian Belajar Siswa di Madrasah Dasar. Jurnal Penelitian Ilmu Pendidikan, 13(1), 22-30. https://doi.org/10.21831/ jpipfip.v13i1.29662

Rohman, F. (2018). Peran Pendidik dalam Pembinaan Disiplin Siswa di Madrasah/Madrasah. Ibya AlArabiyah: Jurnal Pendidikan Bahasa Dan Sastra Arab, 4(1), 72-94. http://jurnal. uinsu.ac.id/index.php/ihya/article/ view/1467

Setiyati, S. (2014). Pengaruh Kepemimpinan Kepala Madrasah, Motivasi Kerja, dan Budaya Madrasah Terhadap Kinerja Guru. Jurnal Pendidikan Teknologi Dan Kejuruan, 22(2), 200-206. https://doi. org/10.21831/jptk.v22i2.8931

Sugeng, H. (2016). Pengaruh Kedisiplinan Siswa dan Motivasi Belajar Terhadap Prestasi Belajar Siswa pada Mata Pelajaran Ekonomi di Sma Swasta Depok. Faktor Jurnal Ilmiah Kependidikan, 3(3), 261-274. http:// dx.doi.org/10.30998/.v3i3.939

Sulhan, A. (2018). Manajemen Pendidikan Karakter Berbasis Budaya Santri dalam Mewujudkan Mutu Lulusan di MA Dakwah Islamiyah Putri Kediri Lombok Barat. Jurnal Penelitian
Keislaman, 14(2), 108-135. https:// doi.org/10.20414/jpk.v14i2.488

Syafaruddin, et. al. (2020). Manajemen Pembelajaran Pendidikan Agama Islam di SDIT Bunayya Pandan Kabupaten Tapanuli Tengah. Auladuna: Jurnal Pendidikan Dasar Islam, 7(1), 32-45. http:// repository.uinsu.ac.id/id/ eprint/8966.

Tamarli. (2009). Strategi Kepala Madrasah Dalam Membina Disiplin di Madrasah. Jurnal Serambi Ilmu, 7(1), 52. http:// jurnal.serambimekkah.ac.id/serambiilmu/issue/archive

Trisnawati, D. D. (2013). Membangun Disiplin dan Tanggung Jawab Siswa SMA Khadijah Surabaya Melalui Implementasi Tata Tertib Madrasah. Kajian Moral dan Kewarganegaraan, 2(1), 397-411. https://jurnalmahasiswa. unesa.ac.id/index.php/jurnalpendidikan-kewarganegaraa/article/ view/2658

Tu'u, T. (2004). Peran disiplin pada perilaku dan prestasi siswa. Grasindo.

Tua, A. G., Tewal, B., \& Karuntu, M. (2014). Konsep Diri, Pendidikan dan Pelatihan, Disiplin Kerja Terhadap Prestasi Kerja Pegawai di Kejaksaan Tinggi Sulawesi Utara. Jurnal EMBA: Jurnal Riset Ekonomi, Manajemen, Bisnis dan Akuntansi, 2(1), 353-362. https:// doi.org/10.35794/emba.v2i1.3948

Zahro, A. M., Sobri, A. Y., \& Nurabadi, A. (2018). Kepemimpinan Perubahan Kepala Madrasah dalam Peningkatan Mutu Pendidikan. JAMP: Jurnal Administrasi dan Manajemen Pendidikan, 1(3), 358-363. http://dx.doi. org/10.17977/um027v1i32018p3358 